\title{
Estrogen Induced Prolactin mRNA Accumulation in Adult Male Rat Pituitary as Revealed by in situ Hybridization
}

\author{
Haruo nOGami, Fujio Yoshimura*, Alberto J. CARrillo, \\ Z. Dave SHARP ANd PETeR J. SHERIDAN \\ Department of Celluler and Structural Biology, The University of Texas, \\ Health Science Center at San Antonio, Taxas 78284, U.S.A. \\ *Department of Anatomy, The Jikei University School \\ of Medicine, Tokyo, Japan
}

\begin{abstract}
Adult male rats were injected with different doses $(1,10$, and $100 \mu \mathrm{g})$ of $17 \beta$-estradiol daily for 5 days, and the changes in prolactin (PRL) mRNA levels were examined by in situ hibridization and cytoplasmic dot blot hybridization using cloned cDNA for rat prolactin mRNA. An increase in cytoplasmic PRL mRNA content was evident in all the animals treated with estrogen as revealed with cytoplasmic dot blot analysis. There were however, no significant differences in PRL mRNA content among the three estradiol treated groups. Cytoplasmic PRL mRNA was also demonstrated by in situ hybridization on the frozen pituitary sections using a ${ }^{3} \mathrm{H}$-labeled PRL cDNA probe. The number of grains per cell was increased after estrogen treatment. ${ }^{3} \mathrm{H}$ thymidine uptake into pituitary cells was also examined in vivo using combined techniques of immunocytochemistry and autoradiography. Although the percentage of immunoreactive PRL cells which took up thymidine in their nuclei increased to more than double after estrogen treatment, the increase in the total number of immunoreactive PRL cells was small. These results suggest that the major effect of estrogen on PRL cells is an increase in the accumulation of PRL mRNA in the individual PRL cells. The number of grains per cell was found to vary from cell to cell, both in control and estrogen treated animals. This variability is discussed in relation to the functional heterogeneity within the PRL cell population.
\end{abstract}

Estrogens stimulate prolactin (PRL) synthesis and secretion from the pituitary gland. Several lines of evidence suggest that this may be the result of an increase in the PRL gene transcription rate (Maurer, 1982; Shull and Gorski, 1984). It has been demonstrated that estrogen increases cytoplasmic PRL mRNA in the in situ pituitary gland

Received February 22, 1985 and in cultured pituitary cells by using techniques such as a filter hybridization assay, a nuclease digestion assay, or an in vitro translation of mRNA fraction followed by immunoprecipitation (Seo et al., 1979a, b; Stone et al., 1977). However, these techniques do not provide any information concerning the events occurring within individual cells. In contrast, the in situ hybridization technique allows one to detect 
mRNA on histological sections and thus examine the level of PRL mRNA in individual cells after estrogen stimulation. In this study, the effects of estrogen on the PRL mRNA content in individual cells of the rat pituitary were examined by in situ hybridization and the changes in the total PRL mRNA concentration in the rat pituitary gland were monitored by the cytoplasmic dot blot hybridization assay. The contribution of cell proliferation to PRL mRNA accumulation in response to estrogen treatment was assessed by injecting ${ }^{3} \mathrm{H}$ thymidine into the control and estrogenized animals followed by autoradiography and immunocytochemistry.

\section{Materials and Methods}

Sprague-Dawley male rats ( 8 weeks old) received injections of 1,10 or $100 \mu \mathrm{g}$ of $17 \beta$ estradiol $\left(E_{2}\right.$, dissolved in sesame oil) for five consecutive days. Control animals were injected with sesame oil only. Twenty-four hr after the last injection, the animals were rapidly decapitated and pituitaries were removed. The pituitaries were either frozen in liquid nitrogen for in situ hybridization or homogenized in $10 \mathrm{mM}$ Tris- $\mathrm{HCl}$ pH 8.0, $1 \mathrm{mM}$ EDTA, (TE) containing $0.5 \%$ Nonidet P-40 by loosely fitted glass homogenizer (10 strokes on ice) and homogenenate processed for the cytoplasmic dot blot assay.

In situ hybridization: Frozen sections were cut from the pituitaries at $4 \mu \mathrm{m}$ thickness, mounted onto the glass slides previously treated with Denhart's solution $(0.02 \%$ bovine serum albumin, $0.02 \%$ polyvinylpyrolidone, $0.02 \%$ Ficoll) and acetylated (Brahic and Haase, 1978), and fixed in $0.5 \%$ glutaraldehyde at $4^{\circ} \mathrm{C}$ for $10 \mathrm{~min}$. The sections were washed with distilled water and treated with Proteinase $\mathrm{K}$ (Boehringer, $1 \mu \mathrm{g} / \mathrm{ml}$ in $10 \mathrm{mM}$ Tris- $\mathrm{HCl}, \mathrm{pH} 7.5,5 \mathrm{mM}$ EDTA) at $37^{\circ} \mathrm{C}$ for $30 \mathrm{~min}$. Then the sections were incubated in hybridization buffer $(300 \mathrm{mM} \mathrm{NaCl}, 5$ $\mathrm{mM}$ EDTA, $100 \mathrm{mM}$ Tris- $\mathrm{HCl}, \mathrm{pH} 7.5,2 \times$ Denhart's solution, 2\% dextran sulfate, $30 \%$ formamide, $100 \mu \mathrm{g} / \mathrm{ml}$ of sheared salmon sperm DNA) at room temperature for $24 \mathrm{hr}$. The radioactive rat PRL cDNA (pPRL-1, generously provided by Dr. R. A. Maurer), was applied to the sections at a concentration of $500 \mu \mathrm{g} / \mathrm{ml}(20 \mu \mathrm{l} /$ slide). PRL cDNA was made radioactive by nick translation (Rigby et al., 1977) using ${ }^{3} \mathrm{H}$ dTTP $(90 \mathrm{Ci} / \mathrm{mmole}$, New England Nuclear). The specific activity of labeled probe was $0.5-1.0 \times$ $10^{7} \mathrm{cpm} / \mu \mathrm{g}$ DNA. The sections were incubated at room temperature for $24 \mathrm{hr}$ in a moist chamber to prevent the sections from drying. After a thorough washing with $2 \times \mathrm{SSC} \quad(\mathrm{SSC}=150 \mathrm{mM}$ $\mathrm{NaCl}, 15 \mathrm{mM}$ sodium citrate, $\mathrm{pH}$ 7.0) and with distilled water, they were dehydrated in graded ethanol solutions. Slides were coated with $1: 1$ diluted photographic emulsion (Kodak NTB-2), dried and exposed in a light-proof box at $-20^{\circ} \mathrm{C}$ for 3 weeks. They were photographically developed and stained with hematoxylin to visualize the nuclei. Two control experiments were carried out to confirm the specificity of the hybridization: 1) section were hybridized with radiolabeled ADNA, 2) sections were hybridized with specific radioactive PRL cDNA with 100 -fold excess unlabeled cDNA.

Cytoplasmic dot blot hybridization: Pituitary homogenates prepared as described above were centrifuged at $13,000 \times \mathrm{g}$ using an Eppendorf microfuge, and the cytosol was removed. After the addition of vanadium ribonucleoside (final conc., $5 \mathrm{mM}$ ) the cytosol was serially diluted with $20 \times$ SSC. An aliquot of the cytosol was saved for protein determination by the method of Lowry et al. (1951). Serially diluted cytosol was blotted onto nitrocellulose filters $(0.45 \mu \mathrm{m})$ supported by a 96-well minifold apparatus (Schleicher and Schuell; Keen, NH.) as described before (White and Bancroft, 1982). As the control, a cytosol from each group was incubated with RNase A $(20 \mu \mathrm{g} / \mathrm{ml} \mathrm{TE})$ at $37^{\circ} \mathrm{C}$ for $30 \mathrm{~min}$ prior to being dotted onto the filter. The filters were dried, baked at $80^{\circ} \mathrm{C}$ for $4 \mathrm{hr}$, and prehybridized overnight in a mixture of $50 \%$ formamide, $2 \times$ SET $(\mathrm{SET}=30 \mathrm{mM}$ Tris- $\mathrm{HCl}, \mathrm{pH} 8.0$, $1 \mathrm{mM}$ EDTA, $150 \mathrm{mM} \mathrm{NaCl}), 2 \times$ Denhart's solution, $0.1 \%$ sodium dodecylsulfate (SDS), $0.1 \%$ sodium pyrophosphate and $100 \mu \mathrm{g} / \mathrm{ml}$ of denatured and sheared salmon sperm DNA at $42^{\circ} \mathrm{C}$ with gentle stirring. The filter was then hybridized with the $75 \mathrm{ng}$ of ${ }^{32} \mathrm{P}$-labeled pPRL-1 $\left(4.2 \times 10^{8} \mathrm{cpm} / \mu \mathrm{g}\right.$ DNA) for $48 \mathrm{hr}$ at $42^{\circ} \mathrm{C}$. After washing with $2 \times$ SSC containing $0.1 \%$ SDS and $0.1 \%$ sodium pyrophosphate at room temperature, the filter was exposed at $-70^{\circ} \mathrm{C}$ with a Kodak XAR-5 film overlayed by Dupont Cornex intensifying screen. For the semi-quantitation of the PRL 
mRNA content in cytosol, the cytoplasmic dots were cut out after the autoradiography, added to $5 \mathrm{ml}$ of scintillation fluid and radioactivity was determined in a scintilation counter.

In vivo ${ }^{3} \mathrm{H}$-thymidine incorporation: Another group of animals, age and sex matched were castrated prior to the following experiment. They were injected for five days both with $0.1 \mu \mathrm{Ci} / \mathrm{g}$ body weight of ${ }^{3} \mathrm{H}$-thymidine (New England Nuclear) twice a day $(10: 00 \mathrm{am}$ and $6: 00 \mathrm{pm})$ and 0,1 or $10 \mu \mathrm{g}$ of $\mathrm{E}_{2}$ once a day for five days. Twenty-four hr after the last estradiol injection (16 hr after the last ${ }^{3} \mathrm{H}$-thymidine injection), the animals were killed by decapitation and pituitaries were fixed in Bouin's fluid at room tmeperature for $48 \mathrm{hr}$. The tissues were dehydrated, and embedded in paraffin. Sections $4 \mu \mathrm{m}$ thick were rehydrated and stained immunocytochemically for rat PRL as described previously (Nogami, 1984). Then the sections were dehydrated, coated with photographic emulsion (Kodak NTB-2) and exposed for 6 months. The slides were then developed and served for the cell count study.

Statistical analysis: Student's $t$-test was employed to determine the significance of difference.

\section{Results}

Dilutions of the cytosol preparations reduced the amount of ${ }^{32} \mathrm{P}$-pPRL-1 hybridized (Fig. 1). Incubation of control samples with RNase A $(20 \mu \mathrm{g} / \mathrm{ml})$ eliminated the specific hybridization, suggesting that the radioactivity on the filter was due to the hybridization of cytoplasmic PRL mRNA to PRL cDNA (data not shown). The level of ${ }^{32} \mathrm{P}$ pPRL-1 hybridization was $539 \pm 60 \mathrm{cpm}$ per $50 \mu \mathrm{g}$ of cytosol protein in control animals. Estrogen treatment apparently increased cytoplasmic PRL mRNA levels to more than double even at the lowest dose tested (Fig. 2). There was no additional rise in the PRL mRNA level with increasing doses of estrogen (Figs. 1, 2).

With the in situ hybridization, the presence of PRL mRNA was seen as silver grains over the cytological sections (Figs. 3-10). After three weeks of exposure, the

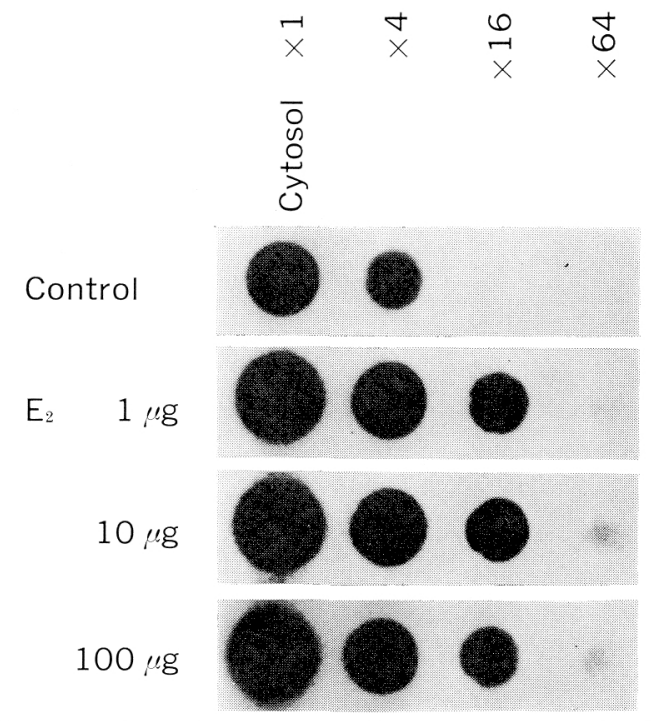

Fig. 1. Cytoplasmic dot blot analysis of PRL mRNA in pituitary cytosol preparations. Adult male rats were castrated and injected with 1 , $10,100 \mu \mathrm{g}$ of $17 \beta$-estradiol daily for 5 days. Control animals received oil injections. Cytosol fractions were prepared as described in materials and methods, and adjusted to 500 $\mu \mathrm{g} / \mathrm{ml}$ in a protein concentration. Serial dilutions $(1 \times, 4 \times, 16 \times, 64 \times)$ were bloted onto the filter, hybridized with ${ }^{32} \mathrm{P}-\mathrm{pPRL}-1$, and exposed for $2.5 \mathrm{hr}$.

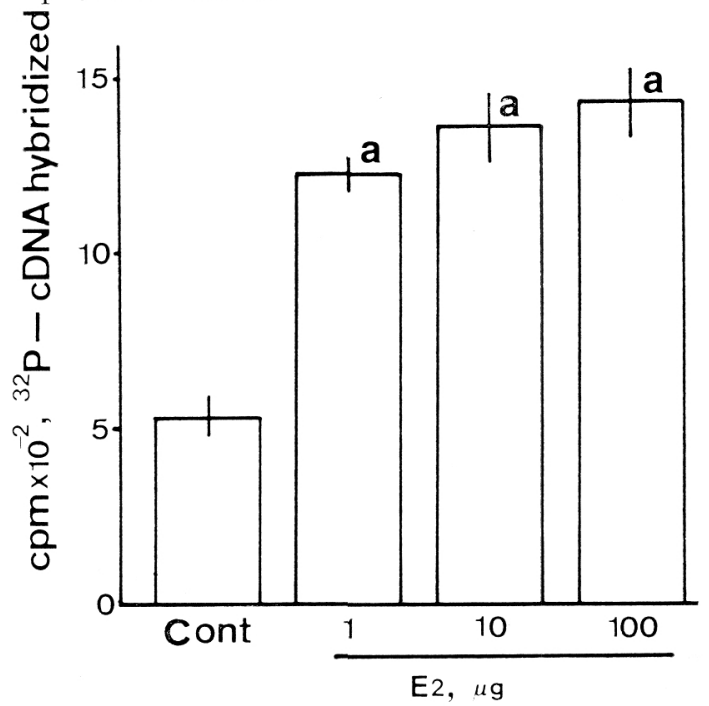

Fig. 2. Amounts of ${ }^{32} \mathrm{P}$-pPRL-1 hybridized to mRNA as determined by cytoplasmic dot blot analysis. Cytoplasmic dots shown in Fig. 1 were cut out and counted. Values are expressed as mean $\pm \operatorname{SEM}(n=4)$. cont: control. a: $\mathrm{p}<0.001$ vs control. 

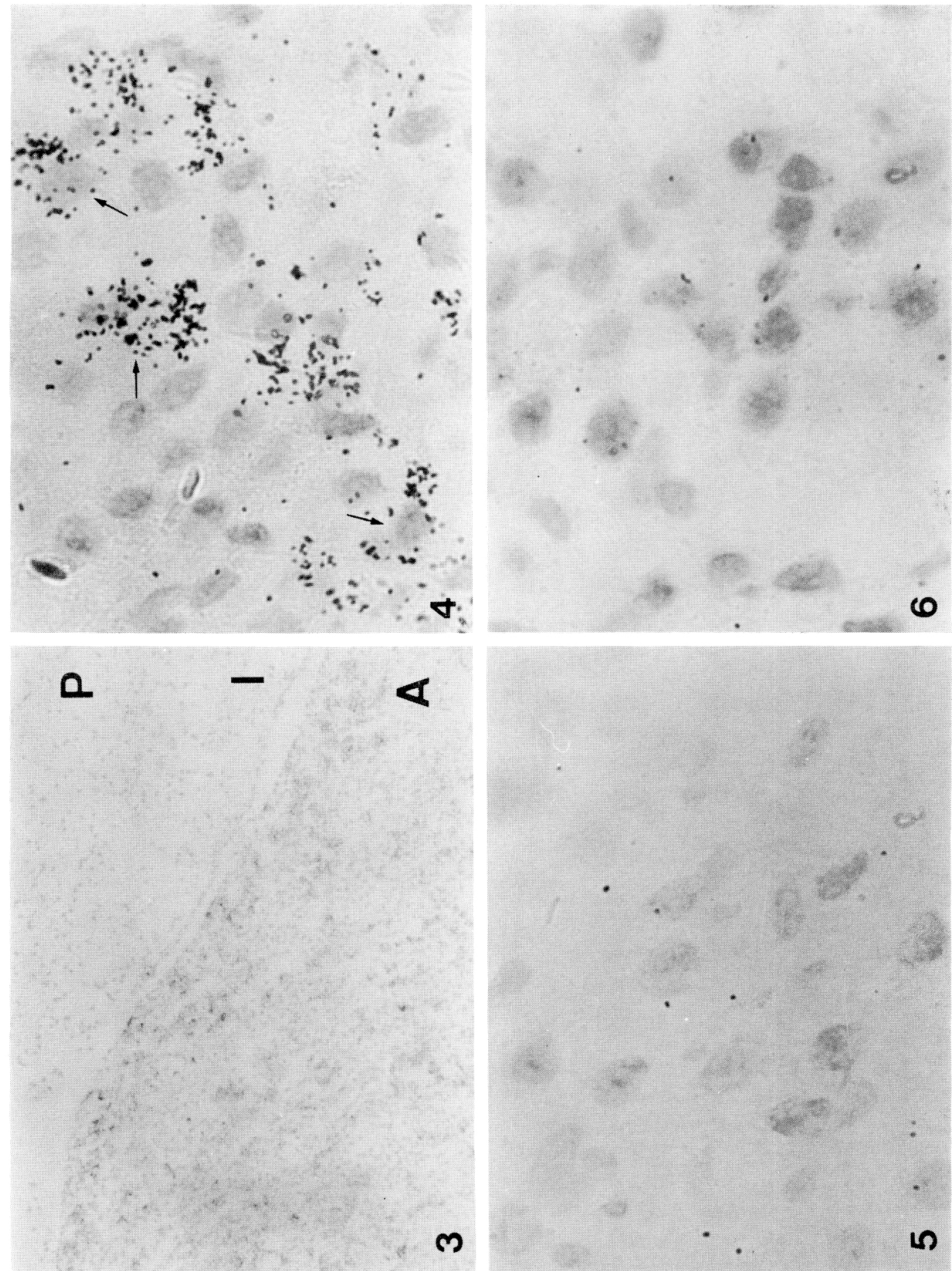


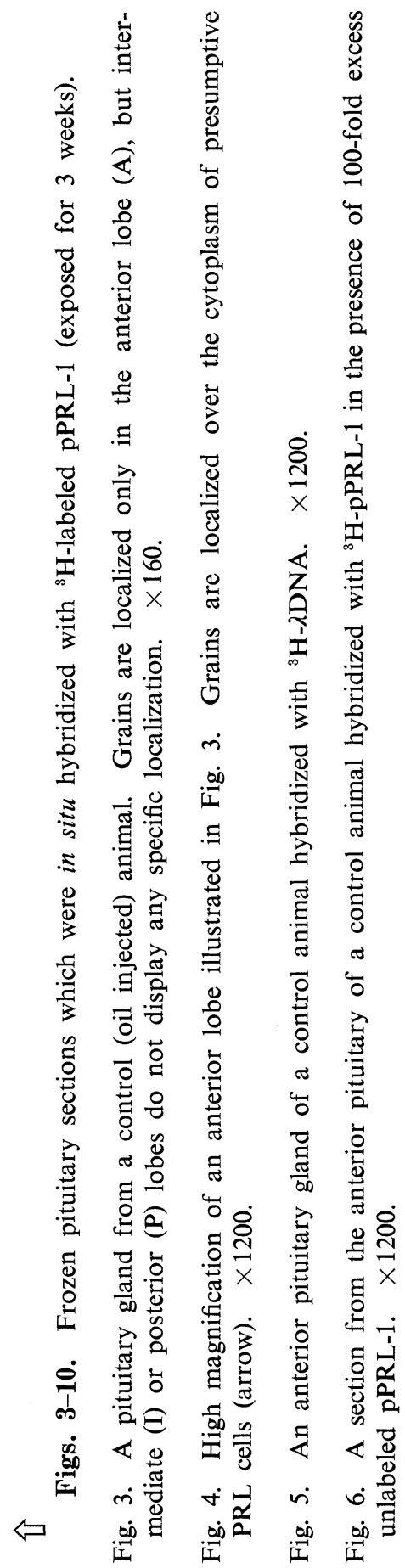

localization of the grains was obvious. Grains were found exclusively over the anterior pituitary. A small number of grains were distributed sparsely over the intermediate and posterior lobes without localizing certain cell types (Fig. 3). In the anterior lobe, the grains were found only in certain cells, presumably PRL cells (Fig. 4). The size, shape and distribution of labeled cells were very similar to those of PRL cells previously identified immunocytochemically (Nogami, 1984). When the sections were hybridized with ${ }^{3} \mathrm{H}-\lambda \mathrm{DNA}$ (Fig. 5 ), or with the specific probe in the presence of 100-fold excess unlabeled probe (Fig. 6), no specific localization was observed.

In order to compare the relative amounts of PRL mRNA in individual PRL cells of the control and estrogen treated animals, the sections from both groups of animals were hybridized, exposed and developed simultaneously (Figs. 7-10). Labeling of the presumptive PRL cells in control animals (Figs. 7,8) was not as heavy as in estrogen treated animals (Figs. 9, 10), although a small number of cells in the control group were heavily labeled (Fig. 8). In the animals which received injections of estradiol $(1,10,100 \mu \mathrm{g})$ for five days (Figs. 9, 10), the increase in the cellular PRL mRNA content was clearly demonstrated as an increase in the number of grains over the cells. The number of grains over a cell was increased in all estrogenized rats to the same extent regardless of the amount of estradiol injected. While a small population of cells had a smaller number of grains over their cytoplasm, most of the cells were labeled heavily in these animals. Thus, the number of grains per cell differed remarkably from cell to cell in both control and three groups of rats which received estrogen.

The cell count data on the thymidine incorporation into immunoreactive PRL cells are shown in Table 1. The number of PRL cells showing incorporation of radio- 

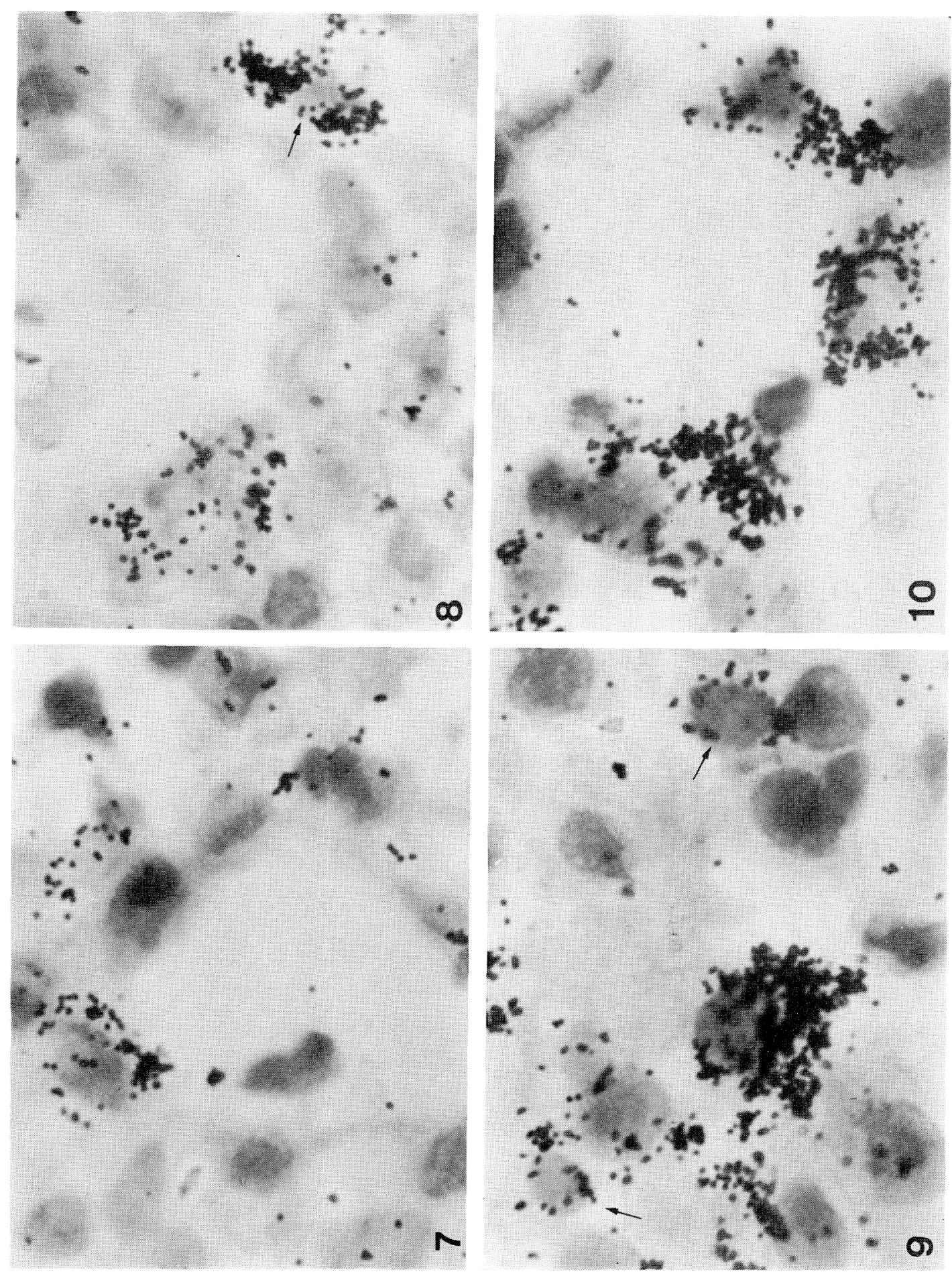

E.
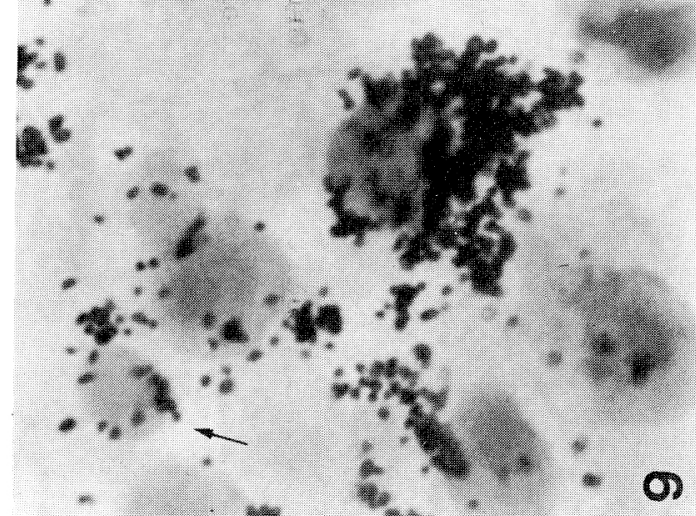
Table 1. ${ }^{3} \mathrm{H}$-Thymidine uptake by immunoreactive prolactin (PRL) cells of estrogenized rats.

\begin{tabular}{lcccccc}
\hline \hline & $\mathrm{n}$ & $\begin{array}{c}\text { Total } \\
\text { PRL } \\
\text { (a) }\end{array}$ & $\begin{array}{c}\text { Total } \\
\text { labeled } \\
\text { (b) }\end{array}$ & $\begin{array}{c}\text { PRL } \\
\text { labeled } \\
\text { (c) }\end{array}$ & $\begin{array}{c}\text { c/a } \\
(\%)\end{array}$ & $\begin{array}{c}\mathrm{c} / \mathrm{b} \\
(\%)\end{array}$ \\
\hline Control & 2 & 208 & 52 & 15 & 7.2 & 28.8 \\
$\mathrm{E}_{2} 1 \mu \mathrm{g}$ & 3 & 230 & 105 & 43 & 18.7 & 41.0 \\
$\mathrm{E}_{2} 10 \mu \mathrm{g}$ & 2 & 252 & 123 & 43 & 17.1 & 35.0 \\
\hline
\end{tabular}

Values are the numbers of cells per $0.1 \mathrm{~mm}^{2}$ of sections of anterior pituitary from control (oil injected) are estrogen treated ( 1 or $10 \mu \mathrm{g} / \mathrm{rat}$, once a day for 5 days) rats, which received injections of ${ }^{3} \mathrm{H}$-thymidine $(0.1 \mu \mathrm{Ci} / \mathrm{g}$ body weight) twice a day for 5 days, (means of 2 or 3 animals). Sections of anterior pituitaries were immunostained for rat PRL, coated with emulsion, exposed for 6 months at $-20^{\circ} \mathrm{C}$, and then developed.

a: Number of immunopositive PRL cells $/ 0.1 \mathrm{~mm}^{2}$.

b: Number of cells labeled with ${ }^{3} \mathrm{H}$-thymidine $/ 0.1 \mathrm{~mm}^{2}$.

c: Number of immunopositive PRL cells which were radiolabeled with ${ }^{3} \mathrm{H}$-thymidine $/ 0.1 \mathrm{~mm}^{2}$.

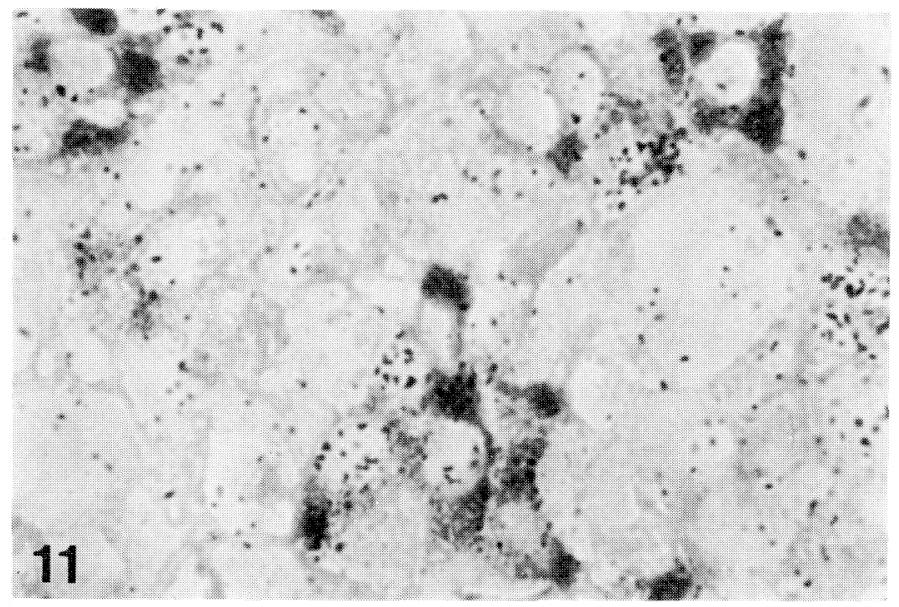

Fig. 11. An autoradiogram of the anterior pituitary of estrogenized rat $(10 \mu \mathrm{g} /$ day, for 5 days) which received injections of ${ }^{3} \mathrm{H}$-thymidine $\quad(0.1 \mu \mathrm{Ci} / \mathrm{g}$ body whight) twice a day for 5 days. The section was immunostained for rat PRL, coated with emulsion and then exposed for 6 months. $\times 1200$.

Figs. 7-8. High magnification of hybridized sections of anterior pituitary from control animal. Several cells are labeled. A small number of the cell are heavily labeled (arrow in Fig. 8). $\times 2400$.

Figs. 9-10. High magnification of hybridized sections of anterior pituitary from animals injected with $100 \mu \mathrm{g}$ of estradiol. Most cells have many more grains over their cytoplasm than those in control animals (See Figs. 7-8). Two cells with a small number of grains are indicated by arrows in Fig. $9 . \quad \times 2400$. Sections illustrated Figs. $7-10$ are processed simultaneously, and exposed for the same duration (3 weeks). active thymidine increased in response to estrogen administration (Fig. 11). However, since the number of total radiolabeled cells also increased, the percentage of radiolabeled immunoreactive PRL cells among total radiolobeled cells showed little change. The density of immunoreactive PRL cells did not show a marked change after estrogen treatment.

\section{Discussion}

Estrogen stimulates PRL production in the pituitary gland. This appears to be 
mediated by two different mechanisms. One of these is the accumulation of PRL mRNA in the cytoplasm, which is considered to be due to the elevation of the PRL gene transcription rate (Maurer, 1982), and the stabilization of cytoplasmic PRL mRNA. The other is the increase in the PRL cell population, which may be brought about both by the proliferation of PRL cells and by the development or differentiation of immature cells into mature PRL cells. Estrogen has been reported to enhance thymidine incorporation into nuclear DNA (Maurer, 1979; Jahn et al., 1972), and to increase PRL cell proliferation in the pituitary gland (Takahashi and Kawashima, 1981; Takahashi et al., 1984). Maurer (1979) suggested that estrogen-induced proliferation of PRL cells is likely to be an important mechanism responsible for developmental changes in the ability of the pituitary to secrete prolactin. In adult male rat pituitary, however, Lieberman et al. (1982) have reported that the mitogenic effect of estrogen might not contribute so much to the rise in the total PRL mRNA level as the stimulatory effect of estrogen on gene transcription. Support for this hypothesis was provided by experiments in which treatment of animals or pituitary cell cultures with hydroxyurea or cytocin arabinoside, agents which partially inhibit DNA synthesis, resulted in only a small decrease in PRL production despite a significant decline in DNA synthesis (Lieberman et al., 1982). Also, Antakly et al. (1980) did not observe any significant increase in the PRL cell population during estrogen stimulation of primary pituitary cell culture, while the steroid markedly increased the PRL concentration in the medium.

The increase in PRL mRNA in the pituitary gland due to estrogen is indicated in this study using cytoplasmic dot blot hybridization, which is known to afford a semi-quantitation of the specific mRNA sequence (Wark and Tashjian, 1983; Carrillo et al., 1985). The results on an in situ hybridization study are in favour of those of dot blot analysis. The increase in the number of grains over the PRL cells is evident after the estrogen treatment. Brahic and Haase (1978) and Saber et al. (1983a, b) have demonstrated that the number of grains over the in situ hybridized sections is proportional to the amount of hybrid formed, and the number of grains reflect the amounts of mRNA sequence of interest. Therefore, the present study indicates that an increase in the PRL mRNA sequence occurs in individual PRL cells following estrogen treatment. This is considered to be a mechanism responsible for an increased accumulation of PRL mRNA in the gland following estrogen injection.

The results of the experiment on ${ }^{3} \mathrm{H}$ thymidine incorporation suggest that estrogen certainly stimulates PRL cell proliferation. However, the stimulative effect of estrogen on pituitary cells in taking up ${ }^{3} \mathrm{H}$-thymidine was not restricted only to PRL cells. The percentage of immunoreactive PRL cells which took up ${ }^{3} \mathrm{H}$-thymidine among total immunoreactive PRL cells was less than $20 \%$ even after estrogen stimulation, while the increase in the PRL mRNA sequence occurred in most of the PRL cells of estrogenized rats treated with 1,10 , or $100 \mu \mathrm{g}$ $\mathrm{E}_{2}$. The increase in the total PRL cell population $\left(11 \%\right.$ or $21 \%$ in 1 or $10 \mu \mathrm{g} \mathrm{E}_{2}$ treated groups, respectively) which may be a result of PRL cell proliferation or development of immature cells into functional PRL cells, is too small to account for the increase in PRL mRNA content following estrogen injection which was indicated by dot blot analysis (more than 130\%). Therefore, it is conceivable that the estrogen induced proliferation of PRL cells does not contribute so much to increased accumulation of PRL mRNA in the gland during such a short term estrogen treatment as that examined in this study. It should be pointed out that the response of the pituitary gland 
to estrogen treatment depends upon the duration of the treatment. Adult animals exposed to a prolonged estrogen treatment responded with an intitial increase in PRL gene transcription followed by an increased PRL cell proliferation (Seo et al., 1979b).

Also of interest in the in situ hybridization studies is the large variation in the number of grains within any treatment group including the control. This may suggest the presence of a heterogeneity in the PRL cell population with respect to the quantity of PRL mRNA in each cell. Certain PRL cells may produce more PRL than others. Compatible with a functional heterogeneity within PRL cells are the findings that there are morphologically distinct sub-populations of PRL cells (Nogami, 1984) and that the quantity of estrogen receptor within PRL cells varies quite dramatically (Herbert and Sheridan, 1983, 1984; Nogami et al., 1985).

One final point which should be noted for future studies is the choice of fixative. While in situ hybridization has been used for many purposes such as detection of viral sequences in infected tissues (Blum et al, 1983; Stroop et al., 1981), and the determination of location of certain genes on chromosomes (Zabel et al., 1983), only Pochet et al., (1981) have successfully demonstrated a PRL mRNA sequence on histological sections of the pituitary gland. The difficulty in demonstrating PRL mRNA reside in the fixative used. Many of the above experiments employed ethanol-acetic acid mixture as a fixative, while others used formalin (Gee et al., 1984), or classical histological fixatives, such as Bouin's solution (McAllister et al., 1983). We have tested several fixatives such as formaldehyde and ethanol-acetic acid mixture but we have not found them suitable. The best results were obtained with glutaraldehyde fixation. A distinct localization of grains was found with a low background and with a good preservation of tissue morphology.

In conclusion, we have successfully dem- onstrated PRL mRNA sequences on pituitary sections and have found that the major effect of estrogen on PRL cells in young adult male rats is to increase PRL mRNA in individual PRL cells. The increase in PRL mRNA in estrogenized rats found with in situ hybridization was compatible with the increase in hybridizable mRNA sequences detected by cytoplasmic dot blot hybridization analysis.

\section{Acknowledgement}

We thank Dr. R. A. Maurer, University of Iowa, Iowa, for generously providing rat prolactin cDNA plasmid, pPRL-1.

\section{References}

Antakly, T., G. Pelletier, F. Zeytinoglu and F. Labrie (1980). Changes in cell morphology prolactin secretion induced by 2-Br-ergocryptine, estradiol and thyrotropin-releasing hormone in rat anterior pituitary cells in culture. J. Cell Biol. 86, 377-387.

Blum, H. E., L. Stowring, A. Figus, C. K. Montgomery, A. T. Haase and G. N. Vyas (1983). Detection of hepatitis B virus DNA in hepatocytes, bile duct epithelium, and vascular elements by in situ hybridization. Proc. Natl. Acad. Sci. USA. 80, 6685-6688.

Brahic, M. and A.T. Haase (1978). Detection of viral sequences of low reiteration frequency by in situ hybridization. Proc. Natl. Acad. Sci. USA. 75, 6125-6129.

Carrillo, A. J., T. B. Pool and Z. D. Sharp (1985). Vasoactive intestinal peptide (VIP) increases prolactin mRNA content in $\mathrm{GH}_{3}$ cells. Endocrinology 116, 202-206.

Gee, C. G., C. C. Chen, J. L. Roberts, R. Thompson and S. J. Watson (1983). Identification of proopiomelanocortin neurons in rat hypothalamus by in situ cDNA-mRNA hybridization. Nature 306, 374-376.

Herbert, D. C. and P. J. Sheridan (1983). Uptake and retention of sex steroids by the baboon pituitary gland-evidence of sexual dimorphism with respect to dihydrotestosterone. Biol. Reprod. 28, 377-383.

Herbert, D. C. and P. J. Sheridan (1984). Identification of the progesterone target cells in the 
female baboon pituitary gland. Biol. Reprod. 30, 479-483.

Jahn, G. A., G. A. Machiavelli, L. E. Kalbermann, I. Szijian, G. E. Alonso and J. A. Burdman (1982). Relationships among release of prolactin, synthesis of DNA and growth of the anterior pituitary gland of the rat: effects of estrogen and sulpiride. J. Endocrinol. 94, 110.

Lieberman, M. E., R. A. Maurer, P. Claude and J. Gorski (1982). Prolactin synthesis in primary cultures of pituitary cells: regulation by estradiol. Mol. Cell Endocrinol. 25, 277-294.

Lowry, O. H., N. J. Rosebrough, A. L. Farr and R. L. Randall (1951). Protein measurement with the folin phenol reagent. J. Biol. Chem. 193, 265-275.

Maurer, R. A. (1979). Estrogen-induced prolactin and DNA synthesis in immature female rat pituitaries. Mol Cell Endocrinol. 13, 291-300.

Maurer, R. (1982). Estradiol regulates the transcription of the prolactin gene. J. Biol. Chem. 275, 2133-2136.

McAllister, L. B., R. H. Scheller, E. R. Kandel and R. Axel (1983). In situ hybridization to study the origin and fate of identified neurons. Science 222, 800-808.

Nogami, H. (1984). Fine structural heterogeneity and morphologic changes in rat pituitary prolactin cells after estrogen and testosterone treatment. Cell Tissue Res. 237, 195-202.

Nogami, H., F. Yoshimura, D. C. Herbert, T. B. Aufdemorte, G. A. Gates, G. R. Holt and P. J. Sheridan (1985). Changes in the nuclear uptake and retention of ${ }^{3} \mathrm{H}$-estrogen in gonadotrophs and lactatrophs as a function of age. Anat. Record 212, 288-291.

Pochet, R., H. Brocas, G. Vassart, G. Toubeau, H. Seo, S. Refetoff, J. E. Dumont and J. L. Pasteel (1981). Radioautographic localization of prolactin messenger RNA on histological sections by in situ hybridization. Brain Res. 211, 433-438.

Rigby, P. W., M. Dieckann, C. Rhodes and P. Berg (1977). Labelling deoxyribonucleic acid to high specific activity in vitro by nick translation with DNA polymerase I. J. Mol. Biol. 113, 237-251.

Sabor, M. A., M. A. Zern and D. A. Shefritz (1983a). Use of in situ hybridization to identify collagen and albumin mRNA in isolated mouse hepatocytes. Proc. Natl. Sci. USA. 80, 4017-4020.
Sabor, M. A., D. A. Shafritz and M. A. Zern (1983b). Changes in collagen and albumin mRNA in liver tissue of mice infected with Schitosoma mamsoni as determined by in situ hybridization. J. Cell Biol. 97, 986-992.

Seo, H., S. Refetoff, N. Scherberg, H. Brocas and G. Vassart (1979a). Isolation of rat prolactin messenger ribonucleic acid and synthesis of the complementary deoxpribonucleic acid. Endocrinology 105, 1481-1487.

Seo, H., S. Refetoff, G. Vassart and H. Brocas (1979b). Comparison of primary and secondary stimulation of male rats by estradiol in terms of prolactin synthesis and mRNA accumulation in the pituitary. Proc. Natl. Acad. Sci. USA. 76, 824-828.

Shull, J. D. and J. Gorski (1984). Estrogen stimulate prolactin gene transcription by a mechanism independent of pituitary protein synthesis. Endocrinology 114, 1550-1557.

Stone, R. T., R. A. Maurer and J. Gorski (1977). Effect of estradiol-17 $\beta$ on prolactin messenger ribonucleic acid activity in the rat pituitary gland. Biochemistry 16, 4915-4921.

Stroop, W. G., J. R. Baringer and M. Brahic (1981). Detection of Theiler's virus RNA in mouse central nervous system by in situ hybridization. Lab. Invest. 45, 504-509.

Takahashi, S. and S. Kawashima (1981). Responsiveness to estrogen of pituitary glands and prolactin cells in gonadectomized male and female rats. Annot. Zool. Japon. 54, 73-84.

Takahashi, S., K. Okazaki and S. Kawashima (1984). Mitotic activity of prolactin cells in the pituitary glands of male and female rats of different ages. Cell Tissue Res. 235, 497502.

Wark, J. D. and A. H. Tashjian, Jr. (1983). Regulation of prolactin mRNA by 1,25-dihydroxyvitamin $\mathrm{D}_{3}$ in $\mathrm{GH}_{4} \mathrm{C}_{1}$ cells. J. Biol. Chem. 258, 12118-12121.

White, B. A. and F.C. Bancroft (1982). Cytoplasmic dot blot hybridization. Simple analysis of relative mRNA levels in multiple small cell or tissue samples. J. Biol. Chem. 257, 85698572.

Zabel, B. U., S. L. Naylor, A. Y. Sakaguchi, G. I. Bell and T. B. Shows (1983). High-resolution chromosomal localization of human genes for amylase, proopiomelanocortin, somatostatin, and a DNA fragment $\left(\mathrm{D}_{3} \mathrm{~S}_{1}\right)$ by in situ hybridization. Proc. Natl. Acad. Sci. USA. 80, 6932-6936. 